\title{
Additive effects of aboveground polyphagous herbivores and soil feedback in native and range-expanding exotic plants
}

\author{
Elly Morriën, ${ }^{1,3}$ Tim Engelkes, ${ }^{1,4}$ And Wim H. van der Putten ${ }^{1,2}$ \\ ${ }^{1}$ Department of Terrestrial Ecology, Netherlands Institute of Ecology (NIOO-KNAW), P.O. Box 50, \\ 6700 AB Wageningen, The Netherlands \\ ${ }^{2}$ Laboratory of Nematology, Wageningen University and Research Centre, P.O. Box 8123, 6700 ES Wageningen, The Netherlands
}

\begin{abstract}
Plant biomass and plant abundance can be controlled by aboveground and belowground natural enemies. However, little is known about how the aboveground and belowground enemy effects may add up. We exposed 15 plant species to aboveground polyphagous insect herbivores and feedback effects from the soil community alone, as well as in combination. We envisaged three possibilities: additive, synergistic, or antagonistic effects of the aboveground and belowground enemies on plant biomass. In our analysis, we included native and phylogenetically related range-expanding exotic plant species, because exotic plants on average are less sensitive to aboveground herbivores and soil feedback than related natives. Thus, we examined if lower sensitivity of exotic plant species to enemies also alters aboveground-belowground interactions. In a greenhouse experiment, we exposed six exotic and nine native plant species to feedback from their own soil communities, aboveground herbivory by polyphagous insects, or a combination of soil feedback and aboveground insects and compared shoot and root biomass to control plants without aboveground and belowground enemies. We observed that for both native and range-expanding exotic plant species effects of insect herbivory aboveground and soil feedback added up linearly, instead of enforcing or counteracting each other. However, there was no correlation between the strength of aboveground herbivory and soil feedback. We conclude that effects of polyphagous aboveground herbivorous insects and soil feedback add up both in the case of native and related range-expanding exotic plant species, but that aboveground herbivory effects may not necessarily predict the strengths of soil feedback effects.
\end{abstract}

Key words: aboveground-belowground interaction; climate change; exotic range-expander; insect herbivores; invasive plants; soil biota; soil pathogens; top-down control.

\section{INTRODUCTION}

Many studies have considered how aboveground or belowground natural enemies may control biomass production and abundance of native or invasive exotic plant species (Bardgett and Wardle 2010). However, there are very few examples of examining how plant control effects of aboveground and belowground enemies may interact and whether these interaction effects may differ between native and invasive exotic plant species. Here we show how aboveground and belowground plant enemies alone or in combination influence biomass production of native and rangeexpanding exotic plant species. Thus far, most studies on aboveground-belowground interactions have focused on influences of aboveground and belowground herbivores, pathogens or mutualists on each other (e.g., Masters et al. 1993, Bennett and Bever 2007) or on

Manuscript received 5 October 2010; revised 24 January 2011; accepted 24 January 2011. Corresponding Editor: D. A. Wardle.

${ }^{3}$ E-mail: e.morrien@nioo.knaw.nl

${ }^{4}$ Present address: Department of Environmental Science, Policy, and Management, University of California, Berkeley, California 94720-3114 USA. interactions between aboveground herbivores and belowground decomposers (Bardgett and Wardle 2003). A number of studies have tested how aboveground and belowground herbivores may influence the composition of plant communities (Brown and Gange 1989, Schädler et al. 2004, Van Ruijven et al. 2005). Few studies, however, have considered how plant exposure to both aboveground and belowground herbivores and pathogens may influence individual plants (Maron 1998).

The possible outcomes of combined effects of aboveground and belowground plant enemies on plant performance may be that the effects add up linearly (additive effects), enhance each other so that the combined effects are stronger than the two individual effects together (synergistic effects), or counteract each other so that the combined effects are weaker than the individual effects together (antagonistic effects). Such additive, synergistic, and antagonistic effects have been observed aboveground, as well as belowground. For example, in papaya (Carica papaya) and hoary cress (Lepidium draba), exposing plant individuals to two or more aboveground herbivore species resulted in additive effects (Fournier et al. 2006, Puliafico et al. 2008), whereas exposing the foredune grass Ammophila arena- 
ria to a number of pathogenic soil fungi and rootfeeding nematodes resulted in synergistic growth reduction effects (De Rooij-van der Goes 1995). The interaction effects of plant enemies may depend on the number of interacting enemy species: effects of rootfeeding nematode species on $A$. arenaria were additive when exposing plants to two species (Brinkman et al. 2008), but antagonistic when testing effects of three nematode species (Brinkman et al. 2005). As far as we know only Maron (1998) tested effects of aboveground and belowground herbivores simultaneously on individual plants. His study on bush lupine (Lupinus arboreus) showed additively negative effects of root-boring moth larvae and flower- and seed-feeding insects on the production of seed pods. This previous work leaves the question still wide open how plant individuals may respond to individual and combined effects of aboveground and belowground enemies.

In field studies, selective aboveground and belowground insecticides showed contrasting effects of chemical insect exclusion on plant community development. Aboveground insecticides enhanced vegetation succession, whereas succession was slowed down by adding belowground insecticides (Brown and Gange 1989, Schädler et al. 2004). Moreover, aboveground insecticides enhanced the abundance of grasses while belowground insecticides enhanced forb cover in plant communities (Brown and Gange 1989). The use of insecticides may be due to unaccounted side effects, for example by altering decomposition and nutrient mineralization. Nevertheless, experimental outdoor mesocosms with and without aboveground and belowground invertebrates had similar effects (Van Ruijven et al. 2005) as the field experiments of Brown and Gange (1989) with insecticides. Therefore, aboveground invertebrate herbivores can have opposite effects on plant community development compared to belowground invertebrate herbivores.

The field studies, however, reported combined effects of individual plant responses to aboveground and belowground herbivory and plant-plant interactions (De Deyn et al. 2007). Hence, whereas these selective removal and addition studies revealed a profound role of aboveground and belowground invertebrates in processes influencing plant community composition, they provide limited insight in the underlying processes. Key questions that remain are, for example, how plant species respond to individual and combined effects of aboveground and belowground natural enemies, and how the sensitivity to aboveground enemies correlates with that to belowground enemies.

The main aim of the present study was to examine how individual plants respond to aboveground and belowground plant enemies and to their combined effects. Based on the previously reported work in aboveground or belowground subsystems, we expected effects varying from additive to synergistic, or even antagonistic. As field experiments suggested different responses of plant community composition to above- ground and belowground plant enemies (Brown and Gange 1989, Schädler et al. 2004, Van Ruijven et al. 2005), we expected that the strength of aboveground effects will not necessarily correlate with the strength of belowground effects. This may be due to defense responses in plants to aboveground herbivores differing from belowground herbivores, or root pathogens (Bezemer and Van Dam 2005, Kaplan et al. 2008, Van Dam 2009).

We included 15 plant species in our study. Nine plant species were natives and six were range-expanding exotic plant species that are rapidly increasing in abundance in the study region (Tamis 2005). Biomass production of the range expanders is less influenced by aboveground and belowground enemies than that of natives (Engelkes et al. 2008), which is similar to crosscontinental invasive plant species (Keane and Crawley 2002, Klironomos 2002, Mitchell and Power 2003, Agrawal et al. 2005, Zhang et al. 2009). As little is known about the combined aboveground-belowground enemy effects to exotic plants (Agrawal et al. 2005), we examined whether individual responses of the exotic range expanders to aboveground and belowground enemies deviates from the responses of native plant species.

As aboveground enemies, we choose the generalist African desert locust Schistocerca gregaria and the green peach aphid (Myzus persicae), because they represent important feeding types (a leaf chewer and a phloem feeder, respectively), and because they are highly polyphagous. Our choice for soil feedback is that this approach integrates effects of plant enemies, symbionts, and decomposer organisms (Bever et al. 1997). Most plant species tested thus far have shown negative soil feedback effects (Bever 2003, Petermann et al. 2008), indicating that effects of soil pathogens overrule those of symbionts and decomposers (Bever et al. 1997). Whereas the range-expanding exotic plant species may experience less control from aboveground or belowground enemies, we expected them to respond similarly to individual vs. combined enemy effects.

Considering the many unknowns, we formulated three null hypotheses, assuming (1) that aboveground and belowground enemy effects would add up in a linear fashion, (2) that this type of addition does not differ between natives and exotic range expanders, and (3) that for both native and exotic plants the strength of aboveground control by polyphagous insects will be indicative of the strength of belowground control by the plant-soil feedback. We tested these hypotheses in a full factorial greenhouse experiment.

\section{Methods}

\section{Selection of plant species, collection of seeds and soil}

We used range-expanding exotics and phylogenetically related native plant species all from the same habitat in order not to confound our comparison with other factors. We collected plant seeds and soil from the 
TABLE 1. Origin and location of plant species used in the experiment.

\begin{tabular}{lllccc}
\hline \hline \multicolumn{1}{c}{ Species } & Origin & Geographical origin & $\begin{array}{c}\text { KFC } \\
\text { 1920-1950 }\end{array}$ & $\begin{array}{c}\text { KFC } \\
\text { 1975-1988 }\end{array}$ & $\begin{array}{c}\text { KFC } \\
\text { 1988-2000 }\end{array}$ \\
\hline Angelica archangelica & exotic & Northeast Europe & 4 & 6 & 7 \\
Angelica sylvestris & native & The Netherlands & 9 & 9 & 9 \\
Artemisia biennis & exotic & North Asia & 0 & 2 & 5 \\
Artemisia vulgaris & native & The Netherlands & 9 & 9 & 9 \\
Centaurea stoebe & exotic & Central Europe & & & 7 \\
Centaurea cyanus & native $\dagger$ & The Netherlands $\dagger$ & 9 & 8 & 9 \\
Centaurea jacea & native & The Netherlands & 9 & 9 & 8 \\
Bidens frondosa & exotic & North America & 6 & 8 & 8 \\
Bidens cernua & native & The Netherlands & 8 & 8 & 9 \\
Bidens tripartita & native & The Netherlands & 9 & 9 & 8 \\
Senecio inaequidens & exotic & South Africa & 0 & 6 & 9 \\
Senecio viscosus & native & The Netherlands & 7 & 8 & 8 \\
Senecio vulgaris & native & The Netherlands & 9 & 9 & 6 \\
Solidago gigantea & exotic & North America & 5 & 7 & 7 \\
Solidago virgaurea & native & The Netherlands & 7 & 7 & \\
\end{tabular}

Notes: The last three columns indicate kilometer frequency classes (KFCs), a measure for the amount of occupied grid cells in The Netherlands (see detailed explanation in Methods). All information is according to the Dutch standard list (Tamis 2005). Centaurea stoebe has very recently invaded in The Netherlands, and therefore no frequency records are available for this plant species.

$\dagger$ Centaurea cyanus is recorded as being archeophyte in The Netherlands. This plant was imported in the Middle Ages from the East Mediterranean area as a crop to use in dye. Since this plant has occurred in The Netherlands for centuries, we treated this species as being native in our experiment.

Millingerwaard (The Netherlands; $51^{\circ} 87^{\prime} \mathrm{N}, 6^{\circ} 01^{\prime} \mathrm{E}$ ), a relatively nutrient-rich nature reserve (due to regular river floods) in the Geldersche Poort region after having made a full overview of the range-expanding exotic plant species in the study area. Then, for each rangeexpanding plant species, we selected a native plant species within the same genus based on similar ecology. The plant pairs used in our experiment were selected using four criteria. First the exotic range-expanding plants should have established in The Netherlands, northwestern Europe, in the 20th century in order to be considered to be recently introduced. Second, they should have increased in national grid cell abundance in the last decades of the 20th century in order to have their expansion response positively correlated to climate warming (Tamis 2005). Third, they should have related native species in the same genus for phylogenetic comparison. And fourth, all native and range-expanding plant species should occur in the same habitat, in order to perform the whole experiment using the same soil.

The underlying information on which we based our choices was derived from the National Standard List of the Dutch flora (Tamis 2005). In this data set, The Netherlands is divided into grid cells of $1 \mathrm{~km}^{2}$. Local plant counts determine whether a grid cell is occupied by a certain plant species or not. This abundance measure ranges from 0 (no grid cells occupied) to 10 (all grid cells occupied). To examine how grid cell abundance increased in the 20th century, data were analyzed between 1902 and 1950, between 1975 and 1988, and between 1988 and 2000. Based on the above four criteria and the availability of seeds for producing seedlings, we were able to select six genera: five from the Asteraceae and one from the Apiaceae family. Three exotic plant species originated from Eurasia and the other three exotics originated from other continents. In three genera, we included two native plant species to be able to see how similar two natives within genus are in their response compared to the exotic range-expander (Table 1).

Seeds were collected from the field or, in a few cases, purchased through a specialized seed supplier who collects seeds from local plant populations. All seeds were surface sterilized by a $1 \%$ hyperchlorite solution and germinated on glass beads supplied with demineralized water at a $10-20^{\circ} \mathrm{C}, 10 \mathrm{~h}$ night: $14 \mathrm{~h}$ day regime for early-summer species and a $15-25^{\circ} \mathrm{C}, 8 \mathrm{~h}$ night: $16 \mathrm{~h}$ day regime for late-summer species. In order to synchronize the ontogeny, germinated seedlings were placed at $4^{\circ} \mathrm{C}$ with continuous illumination until transplantation. After transplantation, dead seedlings were replaced until the third week of the experiment.

The soil samples were collected from five random sites in Millingerwaard, homogenized, as we were not interested in spatial variation in the field, and inoculated into a sterilized sandy loam soil from Mossel, Planken Wambuis $\left(52^{\circ} 06^{\prime} \mathrm{N}, 5^{\circ} 75^{\prime} \mathrm{E}\right)$. The soil sterilization was carried out by gamma radiation ( $25 \mathrm{kGy})$, which eliminated all soil biota (Van der Putten et al. 2007).

\section{Experimental setup}

Phase I: soil conditioning.- - One hundred and fifty 4-L pots were filled with a 5:1 mixture of sterilized soil and inoculum soil. We established 10 replicate pots of each plant species (six exotics and nine natives). Each pot received four seedlings and the experiment was carried out in a greenhouse under controlled conditions $(60 \%$ relative humidity, day $21^{\circ} \pm 2^{\circ} \mathrm{C}$; night $16^{\circ} \pm 2^{\circ} \mathrm{C}$ ). 
Additional light was provided by metal halide lamps (225 $\mu \mathrm{mol} \mathrm{PAR} / \mathrm{m}^{2}$, where PAR is photosynthetically active radiation) to ensure a minimum light intensity during $14 \mathrm{~h}$ daytime. Plants were provided with demineralized water every second day to compensate for water uptake and evapotranspiration. Every week, initial soil moisture level was reset by weighing. In order to prevent plants from becoming nutrient depleted, Hoagland solution was added at a rate of $25 \mathrm{~mL}$ of 0.5 strength per week, which is a dosage that does not prevent the establishment of arbuscular mycorrhizal fungi (Van der Putten et al. 2007). Initial soil nutrient conditions were similar in all pots in the conditioning phase. After 8 weeks of growth, the plants were harvested and the conditioned soils were used for a second growth phase to test the plant-soil feedback effect and the effect of aboveground herbivory.

Phase II: soil feedback.-The conditioned soil from every pot in phase I of the growth experiment was split into two halves. One half was placed in a 1.3-L pot to be called "own" soil. The other half was used to create control soils. The control soil of every plant species contained soil conditioned by all other plant species, excluding plants from the same genus. Because all controls shared soil from five genera, we assumed initial soil nutrient conditions to be similar for all control pots. We established 10 replicates with own and 10 with control soils: each replicate was made from a separate replicate from the soil conditioning phase. Five of the 10 replicate pots with control soils were randomly assigned to an aboveground herbivory treatment. We planted three seedlings per pot. Water, light, and nutrient conditions were supplied as in phase I, except that 10 $\mathrm{mL}$ of 0.5 Hoagland solution was added on a weekly basis because the pots were smaller, there were fewer plants and there was less water loss from the soil surface compared to the 4-L pots. After week 10, all roots and shoots were harvested, air-dried at $70^{\circ} \mathrm{C}$ for $48 \mathrm{~h}$ and weighed as total root and shoot biomass per pot. Relative soil feedback was calculated using total (shoot and root) dry biomass for each replicate separately as: (total biomass own soil - total biomass control soil)/ (total biomass control soil) (Van der Putten et al. 2007). At the end of the soil-feedback phase, we measured mineral nitrogen $\mathrm{NO}_{3}-\mathrm{N}$ and $\mathrm{NH}_{4}-\mathrm{N}$ in $0.01 \mathrm{~mol} / \mathrm{L}$ $\mathrm{CaCl}_{2}$ extract (1 part soil : 10 parts extract) and available phosphorus also in $0.01 \mathrm{~mol} / \mathrm{L} \mathrm{CaCl}_{2}$ extract (1 part soil : 10 parts extract) colorimetrically using a Traacs 800 auto-analyzer (Technicon Systems, Seal Analytical, Mequon, Wisconsin, USA) as a measure of nutrient depletion.

Aboveground herbivory.-In the seventh week, five replicates of the control pots and five replicates of the own pots that had been randomly assigned to the aboveground herbivory treatment were exposed to the locusts (three individuals per pot) and the aphids (five individuals per pot). The African desert locusts (average mass $=0.0858 \mathrm{~g}, n=79$ locusts) and the aphids were prevented from escaping by placing all pots (including those from the soil feedback experiment) individually in spherical nets (diameter $25 \mathrm{~cm}$, height $1.5 \mathrm{~m}$ ). Before the start of the treatment, the locust nymphs were starved for 24 hours. Subsequently, they were allowed to feed for three consecutive weeks until harvest. Once per week, locust survival was determined. The first cohorts of the aphids were reared on white radish (Raphanus sativus) in transparent boxes $(40 \times 50 \times 65 \mathrm{~cm})$, which were stored in a climate room with conditions of $21^{\circ} \mathrm{C}$, $14 \mathrm{~h}$ light: $10 \mathrm{~h}$ dark and 60\% relative humidity. We started with eight maternal lines, which were mixed in the last growth cohort to ensure sufficient genetic diversity before being transferred to the experimental plants. From this rearing, only apterous adults of similar size were selected. Each replicate from each plant species also received five aphids and their total number was counted after 3 weeks.

In phase II, all pots with aboveground herbivory and soil feedback were completely randomized in the greenhouse. Plant biomass was determined as for the soil feedback experiment and relative herbivore effects were calculated within replicates as (shoot biomass with herbivores - shoot biomass without herbivores)/(shoot biomass without herbivores). We also determined locust survival and aphid population growth.

In order to test how the effects of aboveground herbivory and soil feedback were adding up, we compared the sum of the individual effects (predicted effect) with those of the treatments where plants were exposed to both soil feedback and aboveground herbivory (observed effect). Plant biomass in the control soil without herbivores was regarded as the biomass without any inhibitions. Then, the shoot and root biomass reduction for the soil feedback effect (difference between own and control soil) and the effect of herbivore reduction (difference between herbivory and no-herbivory treatment) were calculated for each plant species, added, and compared with the treatment where plants were exposed to the combination of soil feedback and aboveground herbivory (Fig. 2; Haag et al. 2004). Because plant biomass data are always positive they tend to follow a logarithmic distribution when biomass values approach zero, which would transform the linear additive effect towards a multiplicative effect (Slob 1987). Moreover, in the treatment where plants were exposed to both soil feedback and aboveground herbivory, the impact of an aboveground herbivore also may have a negative effect on the belowground root biomass, and the soil community may have a negative effect on shoot biomass (Fig. 1). Therefore, plotting the individual and combined effects on a logarithmic scale gives a more correct representation of the additive effect (Fig. 2).

\section{Statistical analyses}

Effects of herbivores and soil pre-treatment on shoot biomass, root biomass, and (root biomass)/(total 

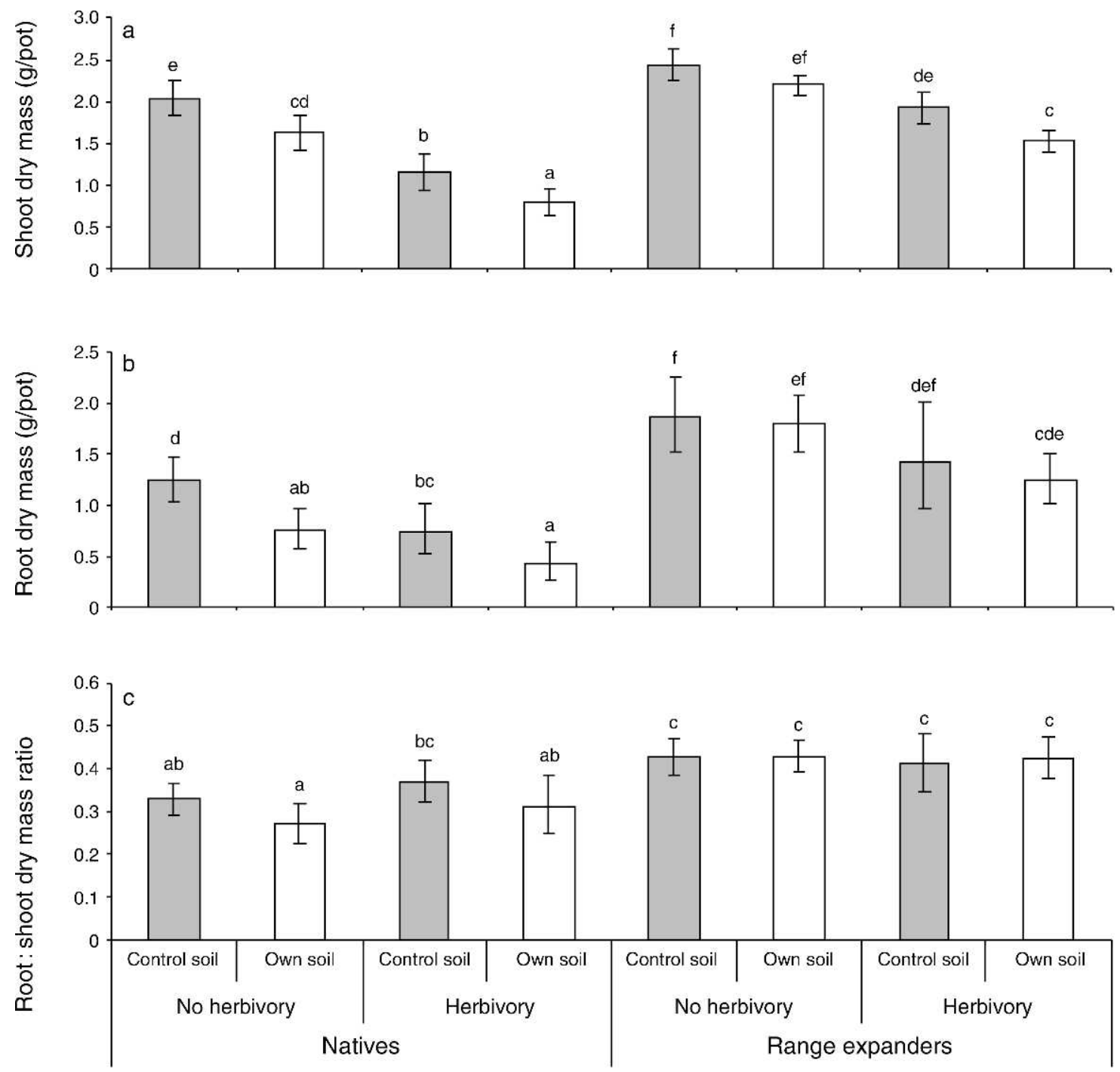

FIG. 1. (a) Shoot dry mass (mean $\pm \mathrm{SE}$ ) of native and range-expanding plant species either exposed or not exposed to herbivores and grown in pots containing own soil (white bars) or control soils (gray bars). Bars show back-transformed means of natural-log-transformed data $(\ln [x+1])$. (b) Root dry mass (mean \pm SE); same experimental design as in panel (a). (c) Root dry mass divided by total dry mass (mean $\pm \mathrm{SE}$ ); same experimental design as in panel (a). In all panels, bars with the same letters above them are not significantly different at $\alpha=0.05$ according to a Tukey's hsd test.

biomass) were analyzed using a full factorial ANOVA, including the effects of herbivore, soil, origin (native or exotic), species (nested in origin), and all their interactions. All variables were considered to be fixed, including species, because we used all species that were available in our experimental site; see the selection criteria as explained above. Additionally, we performed an ANOVA in which we used species as units of replication. In that analysis, herbivory, soil, origin, and all their interactions were used as factors in this analysis. Of primary interest is the soil $\times$ herbivory interaction, indicating whether enemy effects differ in their rank of effect size, as well as the origin $\times$ soil $\times$ herbivory interaction indicating whether the soil $\times$ herbivory interactions differ between native and range-expanding plant species. In order to test for a relationship between effects of aboveground herbivory and soil feedback a Spearman rank order correlation was performed with the species as replicate units. All statistical analyses were carried out in STATISTICA 9 (StatSoft, Inc., Tulsa, Oklahoma, USA). To improve normality and homogeneity of variances of residuals among groups defined by the statistical models, shoot biomass, root biomass, and (root biomass)/(total biomass) were natural-log-transformed $(\ln [x+1])$ prior to analysis.

\section{RESUlts}

The effect of plant species and origin as separate factors had a significant effect on shoot biomass, root biomass, and (root biomass)/(total biomass) (Table 2). 
Range-expanding plants produced on average more shoot and root biomass than their native congeners (Fig. la and b). Range-expanding plants overall had a higher proportion of root biomass than native plants (Fig. 1c). Soil treatments "own" vs. "control" had a significant effect on shoot and root biomass (Table 2). This soil effect could not be explained by differences in levels of available nitrogen or phosphorus between pots with own and control soil, nor between plant species (data not shown). Native plants had a significant reduction in their shoot and root biomass in own soil compared to control soil, whereas range expanders were less reduced (Fig. 1a and b). Shoot herbivory reduced the shoot biomass of all plant species (Table 2, Fig. 1a), and in some plant species shoot herbivory also resulted in less root biomass (Table 2, Fig. 1b). In the analysis where species were treated as replicates the significances of the individual factors followed the same pattern (data not shown).

Native and range-expanding plant species had a significant species(origin) $\times$ soil interaction and $a$ significant species(origin) $\times$ herbivory interaction in the shoots, as well as in the roots (Table 2). This indicates different responses among the plant species to the soil and herbivory treatments (see Appendix: Figs. A1 and A2). The significant species(origin) $\times$ soil interaction in (root biomass)/(total biomass) pointed at different biomass allocation among plant species (Table 2). The significant origin $\times$ soil interaction in the (root biomass)/ (total biomass) indicated that native and range-expanding plants differed in their root/shoot allocation in response to soil feedback (Table 2). This was due to a lower proportional investment in root biomass of native plants in own soil compared to the control soil (Fig. 1c). In the analysis of (root biomass)/(total biomass) using species as replicates the origin effect remained, but the origin $\times$ soil interaction was nonsignificant $\left(F_{1,52}=0.63\right.$, $P=0.432)$. Overall, native plant species were reduced more $(61 \%$ for shoots and $66 \%$ for roots) by the combined effect of aboveground herbivory and soil feedback than were range expanders $(37 \%$ in shoots and $33 \%$ in roots; Fig. 1a and b). This explains the significant interaction effect of origin and herbivory on shoot biomass (Table 2). In the analysis using species as replicates the origin $\mathrm{x}$ herbivory interaction of shoots was not significant anymore $\left(F_{1,52}=1.90, P=0.174\right)$.

There was no significant interaction between feedback from the soil community and aboveground herbivory for shoot or for root biomass or (root biomass)/(total biomass) (Table 2). This indicates that soil feedback and shoot herbivory did not have synergistic or antagonistic interaction effects on the plant biomass, but that these belowground and aboveground effects add up linearly. In the analysis using plant species as replicates, this interaction term also was insignificant. There was no significant three-way interaction between plant origin, soil feedback and aboveground herbivory for shoot and root biomass and (root biomass)/(total biomass) (Table
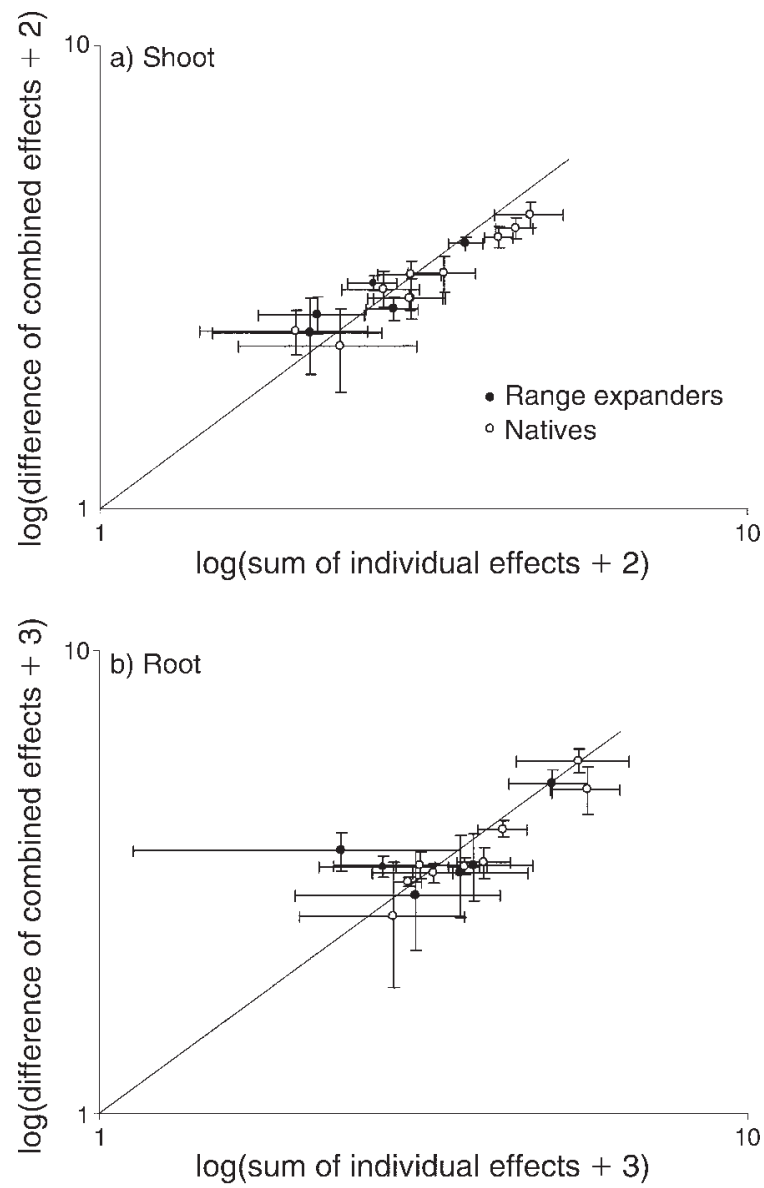

FIG. 2. Sum of the individual effects of shoot herbivory and soil feedback plotted against the combined effects of (a) shoots and (b) roots of nine native species (open symbols) and six range-expanding exotic plant species (solid symbols). Values shown are means \pm SE. In panel (a), for the $x$-axis we used the mean logarithm of the sum of individual effects of aboveground-herbivores-only and soil-feedback-only treatment +2 to be able to plot positive values (originally based on plant biomass data expressed as $\mathrm{g} / \mathrm{pot}$ ). These values were plotted against the logarithm of the difference between combined effects of aboveground herbivores and soil feedback and the control without above- and belowground herbivores +2 . The straight line represents a 1:1 relationship, which would be expected in the case of additive effects. From left to right, symbols represent Bidens tripartita, Bidens frondosa, Solidago gigantea, Angelica sylvestris, Angelica archangelica, Bidens cernua, Senecio inaequidens, Solidago virgaurea, Artemisia biennis (overlaps with $S$. virgaurea), Senecio viscosus, Senecio vulgaris, Centaurea stoebe, Centaurea jacea, Artemisia vulgaris, and Centaurea cyanus. In panel (b), we added +3 in order to obtain positive values; from left to right symbols represent Senecio inaequidens, Angelica archangelica, Angelica sylvestris, Bidens cernua, Bidens frondosa, Bidens tripartita, Solidago virgaurea, Solidago gigantea, Senecio vulgaris, Artemisia biennis, Centaurea cyanus, Senecio viscosus, Centaurea stoebe, Centaurea jacea, and Artemisia vulgaris.

2). This shows that there is no allocation of biomass from the root to the shoot or vice versa as a compensation response to herbivore grazing, neither in the native plants nor in the range expanders. Moreover, 
TABLE 2. ANOVA table of the effect of species nested in origin, origin, soil, herbivory, and all their interactions on shoot biomass, root biomass, and the ratio of root mass to total biomass.

\begin{tabular}{|c|c|c|c|c|c|c|c|c|c|}
\hline \multirow[b]{2}{*}{ Effects } & \multicolumn{3}{|c|}{ Shoot biomass } & \multicolumn{3}{|c|}{ Root biomass } & \multicolumn{3}{|c|}{ Root mass : total biomass } \\
\hline & df & $F$ & $P$ & df & $F$ & $P$ & $\mathrm{df}$ & $F$ & $P$ \\
\hline Species(origin) & 13 & 27.2 & 0.000 & 13 & 10.51 & $<0.001$ & 13 & 19.09 & 0.000 \\
\hline Origin & 1 & 173 & 0.000 & 1 & 120.89 & $<0.001$ & 1 & 56.74 & 0.000 \\
\hline Soil & 1 & 47.5 & 0.000 & 1 & 14.51 & $<0.001$ & 1 & 2.98 & 0.055 \\
\hline Herbivory & 1 & 228 & 0.000 & 1 & 29.35 & $<0.001$ & 1 & 0.97 & 0.251 \\
\hline Species (origin) $\times$ soil & 13 & 3.22 & 0.000 & 13 & 3.83 & $<0.001$ & 13 & 3.10 & 0.000 \\
\hline Species(origin) $\times$ herbivory & 13 & 11.5 & 0.000 & 13 & 2.94 & 0.001 & 13 & 1.36 & 0.077 \\
\hline Origin $\times$ soil & 1 & 1.34 & 0.248 & 1 & 2.11 & 0.119 & 1 & 4.05 & 0.027 \\
\hline Origin $\times$ herbivory & 1 & 19.3 & 0.000 & 1 & 0.06 & 0.882 & 1 & 2.44 & 0.080 \\
\hline Soil $\times$ herbivory & 1 & 1.35 & 0.247 & 1 & 0.00 & 0.890 & 1 & 0.15 & 0.759 \\
\hline Origin $\times$ soil $\times$ herbivory & 1 & 0.75 & 0.387 & 1 & 0.52 & 0.522 & 1 & 0.01 & 0.988 \\
\hline Species (origin) $\times$ soil $\times$ herbivory & 13 & 0.25 & 0.997 & 13 & 0.48 & 0.938 & 13 & 0.92 & 0.447 \\
\hline Error & 210 & & & 215 & & & 208 & & \\
\hline
\end{tabular}

Notes: All data were natural-log-transformed $(\ln [x+1])$ prior to analysis. The effects of species(origin), origin, soil, interaction origin $\times$ soil, and the effects of species(origin), origin, herbivory, and origin $\times$ herbivory on total plant biomass were analyzed before in two separate analyses on two subsets of this data set (Engelkes et al. 2008).

there was no species(origin) $\times$ soil $\times$ herbivory interaction in shoot and root biomass and (root biomass) $/$ (total biomass). This indicates that there were no influences of aboveground herbivory on soil feedback or vice versa and that this is independent of the plant species considered (Table 2).

There was no significant correlation between the relative soil feedback effects and the relative herbivore effects on the individual plant species $\left(n=6\right.$ species; $R^{2}=$ $0.4249, P=0.257$ for the range expanders and $n=9$ species; $R^{2}=0.1437, P=0.333$ for the native plants; data not shown). Therefore, the effect size of aboveground herbivory could not predict the effect size of soil feedback and vice versa. However, the sums of the individual effects of aboveground herbivory-only treatment and soil-feedback-only treatment corresponded well with the combined effect of aboveground and belowground herbivory, suggesting that, under the present growth conditions, combined effects can be estimated from determining shoot herbivory and soil feedback individually. This relation was even stronger in shoots (Fig. 2a) than in the roots (Fig. 2b). In Fig. 2, the data of the range-expanding species were closer to the basis of the graph than of the native plant species. This confirms that the range expanders are less harmed by aboveground herbivores and soil feedback than related natives.

\section{Discussion}

In spite of the growing awareness that plant performance needs to be considered from a combined aboveground-belowground perspective (Bardgett and Wardle 2010), little is known about how aboveground and belowground plant-enemy interaction effects work out at the level of plant individuals. We show that under our experimental conditions adding up the plant responses to the individual effects of aboveground herbivory and soil feedback closely approached the plant responses to combined exposure of aboveground herbivory plus soil feedback (Fig. 2). Thus, our results suggest that combined effects of shoot herbivores and plant-soil feedback on plant biomass development are additive. Interestingly, range-expanding exotic plant species were influenced less by the aboveground and belowground enemies and still showed an additive response to combined exposure comparable to phylogenetically related native plant species. Our results also showed that enemy effects on plant biomass in one subsystem did not influence enemy effects in the other subsystem.

There was no correlation between the effect size of shoot herbivory and the strength of soil feedback. Thus, plant tolerance or resistance to polyphagous aboveground herbivores cannot be used as a predictor of plant sensitivity to soil feedback. These results further explain why, in field studies, aboveground and belowground enemy effects may not work out equally on all plant species present in a community (Van Ruijven et al. 2005), because plant species-specific differences in sensitivity to aboveground or belowground enemies can influence the outcome of plant-plant interactions. The plant species-specific sensitivities to aboveground and belowground enemies may result from, among others, the plant defense pathways involved (Bezemer and Van Dam 2005). Defense against aboveground feeders is mainly through the jasmonic acid pathway, whereas defense against belowground pathogens is regulated more via the salicylic acid pathway (Beckers and Spoel 2006), which is a possible explanation why the strength of aboveground defense against insects does not need to correlate with the strength of plant-soil feedback.

In our study, we analyzed the interaction effects of shoot herbivory and soil feedback on single plants. In mixed plant communities, plant-species-specific aboveground and belowground enemy effects on plant individuals can influence the outcomes of plant-plant interactions, thus enforcing growth reduction initially 
due to plant enemies (Kardol et al. 2007). Competition for abiotic factors, such as nutrients, light, and water play an important role in plant-plant interactions and, therefore, have been used as key factors in explaining plant abundance (Grime 1973, Grace and Tilman 1990). However, these types of interactions need to be integrated with the roles that biotic interactions can have on plant competition, facilitation, and coexistence. For example, aboveground feeding by herbivores and selective effects of pollinators (Levin and Anderson 1970, Carson and Root 2000), as well as belowground effects from the soil community (Bonanomi et al. 2005) all can be involved in influencing plant community composition, apart from resource availability. The variety in responses among individual plant species aboveground or belowground will further enhance the number of possible outcomes of interactions within plant communities.

Our findings also help to further explain why promotion or slowing down succession depends on aboveground and belowground insect control, as well as on successional stage (Brown and Gange 1989, Schädler et al. 2004). Plants that are sensitive to shoot herbivory are not necessarily sensitive to growth reduction by soil biota and vice versa. Such plant sensitivities may vary both within and among succession stages. Our results are not in conflict with studies that have shown aboveground biota to influence belowground biota and vice versa (e.g., West 1995, Bardgett and Wardle 2003), because those studies considered effects of aboveground and belowground second and higher trophic level organisms on each other, instead of considering the combined effects on plants, as we did in our study.

We conclude that aboveground and belowground control of plant biomass production by polyphagous shoot herbivores and plant-soil feedback can add up linearly when acting in concert. Interestingly, these additive effects were observed when considering both native and range-expanding exotic plant species, even though the range expanders were far less influenced by the aboveground and belowground plant enemies. However, the strength of negative soil feedback could not be predicted from the responses of the native and exotic range-expanding plants to polyphagous shootfeeding insects, and vice versa. Population control of climate-warming-induced range-expanding plant species by aboveground and belowground enemies is still a new study area, but it can already be concluded that successful range expanders are less exposed to aboveground (Engelkes et al. 2008) and belowground enemy effects (Van Grunsven et al. 2007, 2010, Engelkes et al. 2008). Our results suggest that ultimately plant population control may originate from additive effects of aboveground and belowground enemies. Which of those enemies will provide strongest control may vary among plant species, due to species-specific differences in their sensitivities to shoot herbivory and soil feedback.

\section{ACKNOWLEDGMENTS}

We thank Staatsbosbeheer Regio Oost for allowing permission to collect soil and seeds in the Millingerwaard; Baudewijn Odé, Wil Tamis, Kees Groen, Arjen Biere, Martijn Bezemer, Jeffrey Harvey, and the late Ruud van der Meijden for discussions; Tineke Vos, Miranda Vlag, and Jinze Noordijk for assistance in the greenhouse; Leo Koopman for providing the locusts; and Jeroen Jansen, Koen Verhoeven, and Peter de Ruiter for statistical advice. This study was funded by ALW-VICI grant to W. van der Putten.

\section{Literature Cited}

Agrawal, A. A., P. M. Kotanen, C. E. Mitchell, A. G. Power, W. Godsoe, and J. Klironomos. 2005. Enemy release? An experiment with congeneric plant pairs and diverse aboveand belowground enemies. Ecology 86:2979-2989.

Bardgett, R. D., and D. A. Wardle. 2003. Herbivore-mediated linkages between aboveground and belowground communities. Ecology 84:2258-2268.

Bardgett, R. D., and D. A. Wardle. 2010. Abovegroundbelowground linkages: biotic interactions, ecosystem processes, and global change. First edition. Oxford University Press, New York, New York, USA.

Beckers, G. J. M., and S. H. Spoel. 2006. Fine-tuning plant defence signalling: salicylate versus jasmonate. Plant Biology $8: 1-10$.

Bennett, A. E., and J. D. Bever. 2007. Mycorrhizal species differentially alter plant growth and response to herbivory. Ecology 88:210-218.

Bever, J. D. 2003. Soil community feedback and the coexistence of competitors: conceptual frameworks and empirical tests. New Phytologist 157:465-473.

Bever, J. D., K. M. Westover, and J. Antonovics. 1997. Incorporating the soil community into plant population dynamics: the utility of the feedback approach. Journal of Ecology 85:561-573.

Bezemer, T. M., and N. M. van Dam. 2005. Linking aboveground and belowground interactions via induced plant defenses. Trends in Ecology and Evolution 20:617-624.

Bonanomi, G., F. Giannino, and S. Mazzoleni. 2005. Negative plant-soil feedback and species coexistence. Oikos 111:311321.

Brinkman, E. P., H. Duyts, and W. H. van der Putten. 2005. Consequences of variation in species diversity in a community of root-feeding herbivores for nematode dynamics and host plant biomass. Oikos 110:417-427.

Brinkman, E. P., H. Duyts, and W. H. van der Putten. 2008. Interactions between root-feeding nematodes depend on plant species identity. Soil Biology and Biochemistry 40:2186-2193.

Brown, V. K., and A. C. Gange. 1989. Differential effects of above-ground and below-ground insect herbivory during early plant succession. Oikos 54:67-76.

Carson, W. P., and R. B. Root. 2000. Herbivory and plant species coexistence: community regulation by an outbreaking phytophagous insect. Ecological Monographs 70:73-99.

De Deyn, G. B., J. van Ruijven, C. E. Raaijmakers, P. C. de Ruiter, and W. H. van der Putten. 2007. Above- and belowground insect herbivores differentially affect soil nematode communities in species-rich plant communities. Oikos 116:923-930.

De Rooij-van der Goes, P. C. E. M. 1995. The role of plantparasitic nematodes and soil-borne fungi in the decline of Ammophila arenaria (L.) link. New Phytologist 129:661-669.

Engelkes, T., E. Morriën K. J. F. Verhoeven, T. M. Bezemer, A. Biere, J. A. Harvey, L. M. McIntyre, W. L. M. Tamis, and W. H. van der Putten. 2008. Successful range-expanding plants experience less above-ground and below-ground enemy impact. Nature 456:946-948. 
Fournier, V., J. A. Rosenheim, J. Brodeur, J. M. Diez, and M. W. Johnson. 2006. Multiple plant exploiters on a shared host: testing for nonadditive effects on plant performance. Ecological Applications 16:2382-2398.

Grace, J. B., and D. Tilman. 1990. Perspectives on plant competition. First edition. Academic Press, San Diego, California, USA.

Grime, J. P. 1973. Competitive exclusion in herbaceous vegetation. Nature 242:344-347.

Haag, J. J., M. D. Coupe, and J. F. Cahill. 2004. Antagonistic interactions between competition and insect herbivory on plant growth. Journal of Ecology 92:156-167.

Kaplan, I., R. Halitschke, A. Kessler, B. J. Rehill, S. Sardanelli, and R. F. Denno. 2008. Physiological integration of roots and shoots in plant defense strategies links above- and belowground herbivory. Ecology Letters 11:841-851.

Kardol, P., N. J. Cornips, M. M. L. van Kempen, J. M. T. Bakx-Schotman, and W. H. van der Putten. 2007. Microbemediated plant-soil feedback causes historical contingency effects in plant community assembly. Ecological Monographs 77:147-162.

Keane, R. M., and M. J. Crawley. 2002. Exotic plant invasions and the enemy release hypothesis. Trends in Ecology and Evolution 17:164-170.

Klironomos, J. N. 2002. Feedback with soil biota contributes to plant rarity and invasiveness in communities. Nature 417:6770 .

Levin, D. A., and W. W. Anderson. 1970. Competition for pollinators between simultaneously flowering species. American Naturalist 104:455-467.

Maron, J. L. 1998. Insect herbivory above- and belowground: individual and joint effects on plant fitness. Ecology 79:12811293.

Masters, G. J., V. K. Brown, and A. C. Gange. 1993. Plant mediated interactions between above- and belowground insect herbivores. Oikos 66:148-151.

Mitchell, C. E., and A. G. Power. 2003. Release of invasive plants from fungal and viral pathogens. Nature 421:625-627.

Petermann, J. S., A. J. F. Fergus, L. A. Turnbull, and B. Schmid. 2008. Janzen-Connell effects are widespread and strong enough to maintain diversity in grasslands. Ecology 89:23992406.
Puliafico, K. P., M. Schwarzlander, B. L. Harmon, and H. L. Hinz. 2008. Effect of generalist insect herbivores on introduced Lepidium draba (Brassicaceae): implications for the enemy release hypothesis. Journal of Applied Entomology 132:519-529.

Schädler, M., G. Jung, R. Brandl, and H. Auge. 2004. Secondary succession is influenced by belowground insect herbivory on a productive site. Oecologia 138:242-252.

Slob, W. 1987. Strategies in applying statistics in ecological research. Dissertation. Free University, Amsterdam, The Netherlands.

Tamis, W. L. M. 2005. Changes in the flora of the Netherlands in the 20th century. Gorteria Supplement 6:154-218.

van Dam, N. M. 2009. Belowground herbivory and plant defenses. Annual Review of Ecology, Evolution and Systematics 40:373-391.

van der Putten, W. H., G. A. Kowalchuk, E. P. Brinkman, G. T. A. Doodeman, R. M. van der Kaaij, A. F. D. Kamp, F. B. J. Menting, and E. M. Veenendaal. 2007. Soil feedback of exotic savanna grass relates to pathogen absence and mycorrhizal selectivity. Ecology 88:978-988.

van Grunsven, R. H. A., W. H. van der Putten, T. M. Bezemer, W. L. M. Tamis, F. Berendse, and E. M. Veenendaal. 2007. Reduced plant-soil feedback of plant species expanding their range as compared to natives. Journal of Ecology 95:1050 1057.

van Grunsven, R. H. A., W. H. van der Putten, T. M. Bezemer, F. Berendse, and E. M. Veenendaal. 2010. Plant-soil interactions in the expansion and native range of a poleward shifting plant species. Global Change Biology 16:380-385.

van Ruijven, J., G. B. De Deyn, C. E. Raaijmakers, F. Berendse, and W. H. van der Putten. 2005. Interactions between spatially separated herbivores indirectly alter plant diversity. Ecology Letters 8:30-37.

West, H. M. 1995. Interactions between arbuscular mycorrhizal fungi and foliar pathogens: consequences for host and pathogen. Pages 79-89 in A. C. Gange and V. K. Brown, editors. Multitrophic interactions in terrestrial systems. Science, Oxford, UK.

Zhang, S., Y. Jin, J. Tang, and X. Chen. 2009. The invasive plant Solidago canadensis L. suppresses local soil pathogens through allelopathy. Applied Soil Ecology 41:215-222.

\section{APPENDIX}

Individual plant shoot and root biomass responses to soil feedback and herbivory (Ecological Archives E092-113-A1). 